\section{Mercado e formação: uma análise crítica da mercantilização da educação profissional no Brasil}

\author{
Jaqueline Ventura \\ Universidade Federal Fluminense, Faculdade de Edu- \\ cação, Niterói, RJ, Brasil. \\ $<$ jaqventura@uol.com.br>
}

LIMA, Marcelo. Trabalho e educação no Brasil: da formação para o mercado ao mercado da formação. Curitiba: CRV, 2016, 130 p.

Em Trabalho e Educação no Brasil: da formação para o mercado ao mercado da formação, o professor Marcelo Lima, da Universidade Federal do Espírito Santo, faz um convite à reflexão crítica baseado em uma inquietante constatação: a mercantilização da educação e, em particular, da educação profissional.

O trocadilho do título, entre 'mercado e formação', traduz o atual movimento de ampliação do caráter privatizante da formação humana. $\mathrm{O}$ livro é composto por seis artigos que nos conduzem a refletir sobre como o viés economicista da educação e, em especial, da qualificação profissional, manifesta-se, atualmente, em dois planos simultâneos: a educação como serviço e a educação como mercadoria.

O primeiro capítulo, “Juventude, Trabalho e Educação", abre o debate com uma reflexão sobre o papel da educação e do trabalho nos dias atuais, relacionando tal debate à situação da juventude no Brasil. O desemprego e a violência no contexto social contemporâneo são discutidos à luz de conceitos como desigualdade, urbanização, ética, educação, invisibilidade e alteridade.

Na sequência, em "A dialética trabalho e educação", o autor busca no marxismo as referências teórico-metodológicas para discutir o processo de autoprodução humana que fundamenta epistemologicamente a pesquisa tratada no livro. Com o título "A qualificação e as mudanças no mundo do trabalho", o terceiro capítulo discute como se dá a qualificação atualmente, considerando as mudanças no mundo do trabalho e suas consequências para a educação profissional.

No capítulo “O desenvolvimento histórico do tempo socialmente necessário para a formação profissional do técnico em eletrotécnica na rede federal", a obra traz um importante e original debate sobre o conceito de 'tempo socialmente necessário para formação profissional', um conceito que relaciona os tempos produtivos e os tempos educativos. $\mathrm{O}$ autor demonstra que há uma tendência de diminuição desse tempo de formação.

Com base em um estudo empírico sobre o tempo de formação do técnico em eletrotécnica na rede federal do Espírito Santo, o autor conclui que houve uma espécie de 'reconfiguração' gradativa dos tempos relativos à formação em diferentes áreas, revelando diferentes concepções pedagógicas para os diversos momentos históricos.

Constata-se que, atualmente, as políticas produzidas na lógica do mercado, como, por exemplo, os cursos do Pronatec - com currículo estreito, imediatista e de baixa carga horária - tendem a esvaziar a base temporal desses currículos para fins de uma formação voltada mais para o trabalho simples do que para o trabalho complexo. Esse movimento restringe a educação às necessidades do campo econômico. Desse modo,

Segundo a perspectiva do discurso hegemônico, um dos meios para superar a suposta carência de formação da força de trabalho brasileira, considerada responsável pela não competitividade do Brasil a nível mundial, é a expansão acelerada da qualificação, bem como o acesso a diferentes níveis de certificação.

Essa diretriz tem criado um lucrativo mercado de transferência de recursos públicos para instituições privadas, ao expandir as vias formativas de caráter precário e aligeirado na rede privada e ampliar as possibilidades de certificação, realizadas, em sua maioria, com negação do direito ao conhecimento. (Ventura, Lessa e Souza, 2018, p. 158)

Na sequência, o capítulo quinto, "Expansão da rede federal: mercantilização e flexibilidade", analisa as metamorfoses da rede federal de educação profissional, tomando como base empírica o desenvolvimento histórico dos modelos pedagógicos dessa modalidade de ensino ofertada pelo governo federal no estado do Espírito Santo.

Interessante notar que, ao longo da história, foram construídas marcas identitárias distintas 
para essa instituição educacional. Desde as escolas de aprendizes artífices até os institutos federais de hoje, cada período foi marcado por um tipo de homem que se deseja formar, ou seja, por um projeto educativo que caracterizou o projeto formativo da instituição.

No atual momento histórico, os Institutos Federais de Educação, Ciência e Tecnologia, em um movimento de ampliação e expansão de seu foco, abrangem de cursos de formação inicial e continuada (FIC) até a Pós-Graduação Stricto Sensu. Assim, a flexibilidade e a diversificação de oferta de cursos marcam a sua identidade hoje.

Esse movimento "pseudocria" o direito à educação (expande a rede federal, mas subsidia o setor privado), escondendo seu principal objetivo que é: resolver problema de formação para o mercado pela via da criação do mercado da formação. A criação desse híbrido, anfíbio e IFLEX permite a construção de uma identidade movente e fluída, elástica e adaptável às demandas do mercado. Combinar políticas neodesenvolvimentistas com políticas neoliberais coloca o governo e sua política numa encruzilhada que expressa uma ambiguidade ideológica, mas no fundo se alicerça na complementaridade de ações concretas que se estruturam na flexibilização e na heterogeneização dos tipos de oferta (e de ofertantes) da educação profissional, com o fito de resolver o (pseudo) problema de formar para o mercado pela via do fomento do mercado da formação. (Lima, 2016, p. 105, grifo nosso)

Encerra o livro o capítulo "Centros Públicos de Qualificação Profissional", com a defesa de se reafirmar o caráter público da formação dos trabalhadores. Esse capítulo retoma a proposta de centros públicos de educação, defendida pelo grupo de trabalho $\mathrm{n}^{\circ} 09$ - Trabalho e Educação, da Associação de Pesquisa e Pós-Graduação em Educação - Anped, em meados da década de 1990 e reafirma a atualidade desta proposta contrahegemônica.

O capítulo chama a atenção para o fato de que a educação profissional básica, relacionada ao ensino fundamental, voltada para a formação em ocupações subtécnicas, seja oriunda do sistema S ou das políticas do Ministério do Tra- balho e Emprego, como o o Programa Nacional de Inclusão de Jovens (Projovem), o Programa Nacional de Integração da Educação Profissional com a Educação Básica na Modalidade de Educação de Jovens e Adultos, cursos de formação inicial e continuada (Proeja-FIC) ou o Programa Nacional de Acesso ao Ensino Técnico e Emprego (Pronatec), apresenta, de modo geral, currículos restritos, com conteúdo de menor complexidade e com uma leitura superficial da ciência e o domínio prático das atividades de produção.

Em suma, um currículo que reproduz as posições subalternas dos trabalhadores manuais. Além disso, o "processo de minimização da intervenção do estado nas áreas sociais também tende a diminuir a qualidade e quantidade da oferta escolar tipicamente estatal" (Lima, 2016, p. 124).

Em perspectiva contrária à oferta privada de educação profissional, o autor apresenta a proposta do centro público de educação profissional. Essa proposta alternativa, o projeto do Centro de Referência do Trabalho, a 'Fábrica do Trabalho', executado pela Secretaria de Trabalho e Geração de Renda da prefeitura de Vitória, em 2006, decorreu da crítica à lógica mercantil e significou uma alternativa pública, proposta pelo campo crítico.

A materialização do projeto 'Fábrica do Trabalho' não ocorreu. Embora a obra das instalações físicas tenha sido construída, disputas políticas internas fizeram com que o projeto político-pedagógico original não chegasse a ser efetivado.

Na conclusão, o autor chama atenção para o seguinte: a concepção privatista da formação profissional associada "à mediocridade política vigente, que se alicerça no personalismo e no marketing eleitoral, num momento de perda de hegemonia do governo do qual emergiu esse projeto" (Lima, 2016, p. 125, grifo do autor) inviabilizou a construção desse centro público de educação profissional.

A obra em exame, Trabalho e Educação no Brasil: da formação para o mercado ao mercado da formação, é fruto de um estudo apurado e crítico. É um livro produzido por quem está preocupado em elucidar e transformar a realidade social e, por isso, é uma valiosa contribuição ao nosso pensar e fazer transformador também.

Ela nos oferece uma boa reflexão sobre as relações entre mercado e formação. E, principalmente, nos três últimos capítulos, oferece-nos uma análise crítica sobre a mercantilização da educação profissional no Brasil. 


\section{Referências}

LIMA, Marcelo. Trabalho e educação no Brasil: da formação para o mercado ao mercado da formação. Curitiba: CRV, 2016, 130 p.

VENTURA, Jaqueline P.; LESSA, Ludmila L.; SOUZA, Samantha C. V. Pronatec: ampliação das ações fragmentárias e intensificação da privatização da formação do trabalhador. Revista Trabalho Necessário, ano 16, n. 30, 2018. 